\title{
Differential expression of gonadotropin and estrogen receptors and oocyte cytology during follicular maturation associated with egg viability in European eel (Anguilla anguilla)
}

da Silva, Filipa F. G.; Tveiten, Helge; Maugars, Gersende; Lafont, Anne-Gaëlle; Dufour, Sylvie; Støttrup, Josianne Gatt; Kjørsvik, Elin; Tomkiewicz, Jonna

\section{Published in:}

Comparative Biochemistry and Physiology - Part A: Molecular \& Integrative Physiology

Link to article, DOI:

10.1016/j.cbpa.2018.03.010

Publication date:

2018

Document Version

Peer reviewed version

Link back to DTU Orbit

\section{Citation $(A P A)$ :}

da Silva, F. F. G., Tveiten, H., Maugars, G., Lafont, A-G., Dufour, S., Støttrup, J. G., Kjørsvik, E., \& Tomkiewicz, J. (2018). Differential expression of gonadotropin and estrogen receptors and oocyte cytology during follicular maturation associated with egg viability in European eel (Anguilla anguilla). Comparative Biochemistry and Physiology - Part A: Molecular \& Integrative Physiology, 221, 44-54. https://doi.org/10.1016/j.cbpa.2018.03.010

\section{General rights}

Copyright and moral rights for the publications made accessible in the public portal are retained by the authors and/or other copyright owners and it is a condition of accessing publications that users recognise and abide by the legal requirements associated with these rights.

- Users may download and print one copy of any publication from the public portal for the purpose of private study or research.

- You may not further distribute the material or use it for any profit-making activity or commercial gain

- You may freely distribute the URL identifying the publication in the public portal 
1 Differential expression of gonadotropin and estrogen receptors and oocyte cytology during

2 follicular maturation associated with egg viability in European eel (Anguilla anguilla)

3 Filipa F.G. da Silva ${ }^{1}$, Helge Tveiten ${ }^{2}$, Gersende Maugars ${ }^{3}$, Anne-Gaëlle Lafont ${ }^{3}$, Sylvie Dufour ${ }^{3}$,

4 Josianne G. Støttrup ${ }^{1}$, Elin Kjørsvik ${ }^{4}$, Jonna Tomkiewicz ${ }^{1}$

$6 \quad{ }^{1}$ National Institute of Aquatic Resources, Technical University of Denmark, Kemitorvet, 2800 Kgs.

7 Lyngby, Denmark

$8 \quad{ }^{2}$ Norwegian Institute of Fisheries and Food Research - Nofima AS, Muninbakken 9-13, Breivika, 9291

9 Troms $\varnothing$, Norway

$10{ }^{3}$ Museum National d'Histoire Naturelle, Sorbonne Universités, Research Unit BOREA, UPMC, CNRS,

11 IRD, UCN, UA, 7 rue Cuvier, CP 32, 75231 Paris, France

$12{ }^{4}$ Department of Biology, Norwegian University of Science and Technology, 7491 Trondheim, Norway

$14 *$ Corresponding author:

15 Filipa F.G. da Silva

16 National Institute of Aquatic Resources, Technical University of Denmark, Kemitorvet, 2800 Kgs.

17 Lyngby, Denmark

18 Phone: +4421125086

19 E-mail:fdsi@aqua.dtu.dk 


\section{Abstract}

In captivity, oogenesis and ovarian follicle maturation in European eel can be induced experimentally using hormonal therapy. The follicle's ability to respond effectively to the induction of maturation and ovulation, resulting in viable eggs, depends on the oocyte stage at the time of induction. We hypothesized that variation in the expression of key hormone receptors in the ovary and size of oocyte lipid droplets are associated with changes in oocyte stage. Thus, we induced ovarian follicle maturation using a priming dose of fish pituitary extract followed by an administration of $17 \alpha, 20 \beta$-dihydroxy-4pregnen-3-one (DHP). Females were then strip-spawned, the eggs were fertilized in vitro, incubated and larval survival was recorded at 3 days post hatch (dph). The expression of gonadotropin receptors (fshr, lhcgrl and lhcgr2) and estrogen receptors (esr1, esr2a, esr2b, gpera and gperb) was quantified and the size of oocyte lipid droplets measured. Larval survival at $3 \mathrm{dph}$ was used to differentiate highand low-quality egg batches. Results showed significantly higher abundance of lhcgrl and esr2a at priming for high-quality egg batches whereas $f s h r$ and gperb transcripts were significantly higher at DHP injection for low-quality egg batches. Therefore, high levels of lhcgrl and esr2a may be important for attaining follicular maturational competence, while high $f s h r$ and gperb mRNA levels may indicate inadequate maturational competence. Furthermore, lipid droplet size at DHP and in ovulated eggs was significantly smaller in high-quality egg batches than in low-quality, which indicates that droplet size may be a useful marker of follicular maturational stage.

Key words: estrogen receptors, gonadotropin receptors, lipid droplet, follicular maturation, egg quality 
41 The oceanic, reproductive stages of European eel (Anguilla anguilla) remain undiscovered and sexual maturation neither occurs naturally in their continental habitats nor in captivity. This arrested development results from a strong dopaminergic inhibition (Dufour et al., 1988; Vidal et al., 2004) and a deficient pituitary gonadotropic function, i.e. both gonadotropin synthesis and release are low (Dufour et al., 1983). Experimentally, gonadal development can be induced using hormonal treatments based on fish pituitary extracts in females and human chorionic gonadotropin in males (Fontaine et al. 1964; Yamamoto and Yamauchi, 1974; Dufour et al., 1989; Ohta et al., 1996; Pedersen, 2003). In females, such treatment leads to oocyte growth until maturation. Induction of follicular maturation and ovulation generally requires an additional dose of pituitary extract and an injection of a maturation-

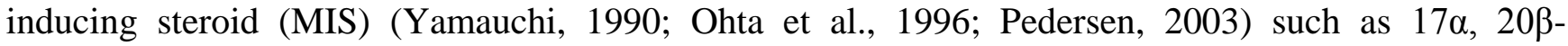
dihydroxy-4-pregnen-3-one (DHP) in the case of the eel. Recent advances in eel assisted reproductive technology have enabled the production of viable eggs and yolk-sac larvae (Butts et al., 2016; Sørensen et al., 2016). However, resulting egg quality is variable and low fertilization rate and poor larval survival are often observed. Variation in egg quality is partly related to the timing induction of ovarian follicle maturation and ovulation, as previous studies have shown that hormonal treatment given too early or too late in the reproductive cycle can be ineffective or inefficient (Palstra et al. 2005; Mylonas et al., 2010; Unuma et al., 2011). Because hormones need to bind to receptors to exert their biological function, differences in responsiveness to hormonal treatment could be due to differences in hormone receptor expression. In teleost fishes, as in other vertebrates, the two pituitary gonadotropin hormones follicle-stimulating hormone $(\mathrm{FSH})$ and luteinizing hormone $(\mathrm{LH})$ play major roles in the regulation of oogenesis and 
62 production of sex steroids (Pierce and Parsons, 1981). Gonadotropic function is mediated by specific

63 membrane receptors, the FSH receptor (FSHR) and the LH receptor (LHCGR), which corresponds to

64 the human LHCGR. These are mainly expressed in the somatic cells of the gonads (Rosenfeld et al.,

65 2007), though they can also be expressed in germ cells (Chauvigné et al., 2014). Until recently, it was

66 accepted that teleosts had a single FSHR and a single LHCGR encoded by $f$ shr and lhcgr genes,

67 respectively. However, in addition to $f$ shr, Maugars and Dufour (2015) identified and characterized two

68 lhcgr genes (lhcgrl and lhcgr2) in some fish species, including the European eel. European eel lhcgrl

69 corresponds to the LHCGR previously characterized in the Japanese eel (Anguilla japonica) (Kazeto et

70 al, 2012). In comparison to the many studies on FSH and LH, knowledge about their receptors in

71 teleost species is still limited.

72 Sex steroids, such as estrogens, are also well-known for their role in reproductive function. In female 73 fish, estrogens (primarily estradiol-17ß, E2) are involved in the regulation of oogenesis and 74 vitellogenesis (Wallace, 1985) as well as in the feedback control of gonadotropin expression and 75 release (Zohar et al., 2010). Estrogens can diffuse through the cell membrane and bind to nuclear 76 estrogen receptors (ESRs). Two distinct subtypes of nuclear ESRs, esrl and esr2, have been cloned 77 from several mammalian and non-mammalian vertebrates (Mosselman et al. 1996; Hawkins et al., 78 2000). In teleosts, including the European eel, two paralogs of esr2 have been reported, esr2a (also 79 named $\operatorname{er} \beta 2$ ) and $\operatorname{esr} 2 b$ (also named er $\beta 1$ ) (Hawkins et al., 2000; Ma et al., 2000; Menuet et al., 2002; 80 Nagler et al., 2007; Lafont et al., 2016). In addition, estrogens can also activate receptors on the cell 81 surface, initiating rapid and often non-genomic biological responses (Watson and Gametchu, 1999; 82 Falkenstein et al., 2000; Norman et al., 2004). The human G-protein coupled receptor 30 (GPER30 or 83 GPER) was shown to have the binding characteristics of an E2 membrane receptor (Revankar et al., 
84 2005; Thomas et al., 2005). Subsequent studies in zebrafish, Atlantic croaker (Micropogonias

85 undulatus) and common carp (Cyprinus caprio) have also shown that estrogens produced by follicle 86 cells inhibit or delay spontaneous follicular maturation via the activation of membrane receptors (Pang 87 et al., 2008; Pang and Thomas, 2009; Peyton and Thomas, 2011; Majumder et al., 2015). In the 88 European eel and some other teleosts, two paralogous gper genes (gpera and gperb) have been recently 89 identified (Lafont et al. 2016) but their roles have not yet been investigated.

90 During follicular maturation, cytological changes in the oocytes take place. This includes migration of 91 the germinal vesicle towards the oocyte periphery followed by breakdown of the nuclear envelope, and 92 meiotic resumption (Lubzens et al., 2017). In many teleosts, including the eel, another feature of oocyte 93 cytoplasmic maturation is the coalescence of lipid droplets to form one or a few large oil globules 94 (Kagawa, 2013). These cytological changes have been used as biomarkers for assessment of oocyte 95 maturational status in relation to assisted reproduction of eel (Palstra et al., 2005; Unuma et al., 2011).

The main objective of this study was to assess the expression of gonadotropin receptors (fshr, lhcgrl and $l h c g r 2$ ) and estrogen receptors (esrl, esr2a, esr2b, gpera and gperb) during induced maturation and ovulation and investigate their relation with subsequent egg quality, ultimately estimated as fertilization rate, hatching success and early larval survival. Finally, concomitant changes in oocyte

100 lipid droplet size were evaluated as potential cytological biomarker of follicular maturational status.

\section{Materials and Methods}

\subsection{Ethics statement}

103 All fish were handled in accordance with the European Union regulations concerning the protection of 104 experimental animals (Dir 86/609/EEC). Eel experimental breeding protocols were approved by the 
105 Animal Experiments Inspectorate (AEI), Danish Ministry of Food, Agriculture and Fisheries (permit number: 2010/561-1783). All efforts were made to minimize animal handling and stress.

\section{$107 \quad 2.2 \quad$ Experimental animals and rearing conditions}

108 Female silver eels $(\mathrm{n}=10$; mean length and weight $\pm \mathrm{SD}$ were $72 \pm 11 \mathrm{~cm}$ and $781 \pm 393 \mathrm{~g}$,

109 respectively) were caught from a freshwater lake (Vandet Sø) in northern Jutland (Denmark) and 110 transported to a research facility of the Technical University of Denmark located at Lyksvad Fish Farm

111 (Vamdrup, Denmark). Eels were randomly distributed into duplicate $300 \mathrm{~L}$ tanks equipped with a 112 recirculation system and gradually acclimated to artificial saltwater over a period of two weeks, i.e.

113 freshwater adjusted to $36 \mathrm{ppt}$ salinity using Tropic Marin Sea Salt (Dr. Biener GmbH, Wartenberg,

114 Germany). Thirty male eels (body weight $106 \pm 13 \mathrm{~g}$; body length $38 \pm 2 \mathrm{~cm}$ ) reared on DAN-EX

1152848 (BioMar A/S, Brande, Denmark) were obtained at a commercial eel farm (Stensgård Eel Farm

116 A/S, Randbøl, Denmark), transported to Lyksvad Fish Farm and kept in separate tanks under the same

117 conditions as the female eels. At the onset of hormonal treatment, the eels were anaesthetized

118 individually in an aqueous solution of benzocaine (ethyl p-aminobenzoate, $20 \mathrm{mg} / \mathrm{L}$, Sigma-Aldrich,

119 Germany), tagged with a passive integrated transponder (pit-tag) in the abdominal muscle, and body

120 weight and length were measured. Throughout the experiment, all fish were maintained at $\sim 36 \mathrm{ppt}$

121 salinity, $\sim 20^{\circ} \mathrm{C}$, and a natural local daily photoperiod. No feed was provided during experiments since

122 eels in the migratory, silvering stage cease feeding (Lokman et al., 2003).

\section{$123 \quad 2.3 \quad$ Induction of gametogenesis and sampling}

124 Females received weekly intramuscular injection of salmon pituitary extract (SPE) at a constant dosage

125 of $18.75 \mathrm{mg} / \mathrm{kg}$ initial body weight to induce and sustain follicular development and vitellogenesis

126 (Kagawa et al., 2005; Tomkiewicz et al., 2012). The first injection was given concurrent with pit- 
127 tagging and regular treatment lasted 16-20 weeks depending on the responsiveness of the females.

128 Pituitary extract was prepared using freeze-dried salmon pituitaries (Argent Chemical Laboratories,

129 Washington, USA) that were grinded, diluted in $\mathrm{NaCl} 0.9 \mathrm{~g} / \mathrm{L}$ and centrifuged according to Ohta et al.

130 (1996, 1997). Supernatants were stored at $-20{ }^{\circ} \mathrm{C}$ until use. Females were weighed at the weekly

131 injections to follow changes in body weight.

132 Individual treatment for follicular maturation and ovulation was initiated at first signs of the onset of 133 oocyte hydration, i.e. a body weight increase of $10-15 \%$ compared to the initial weight and a soft 134 abdomen (Pedersen, 2003, 2004). To assess oocyte developmental stage, each female was 135 anaesthetized in an aqueous solution of benzocaine, and an ovarian biopsy $(\sim 0.2 \mathrm{ml})$ was obtained, 136 using a sterile disposable injection needle ( $16 \mathrm{G}$ x $\left.1 \frac{11 / 2}{2}\right)$. The biopsy was taken at a standard location on

137 the left side of the body $\sim 5-10 \mathrm{~cm}$ anterior to the genital pore, relative to female size, and the female 138 thereafter transferred to a separate tank under the same conditions for individual care. The biopsy was 139 inspected under the microscope and oocyte development graded on a scale from 1-7 according to 140 Palstra et al. (2005). Progression of oocyte maturation varied in time and homogeneity, so each female 141 was followed until the most developed oocytes exhibited characteristics close to stage 4, i.e., fully 142 transparent oocyte with nucleus at periphery (Fig. 1). At this stage, an additional SPE injection as 143 primer was given to females to sustain and boost follicular development (Pedersen, 2004; Kagawa et 144 al., 2005). To complete follicular maturation and induce ovulation, the eel maturation inducing steroid, $14517 \alpha, 20 \beta$-dihydroxy-4-pregnen-3-one (DHP crystalline, Sigma-Aldrich Chemie, Steinheim, Germany) 146 was given $\sim 24 \mathrm{~h}$ later at a dose of $2 \mathrm{mg} / \mathrm{kg}$ present body weight (Ohta et al., 1996). Prior to DHP 147 injection, a new biopsy $(\sim 0.2 \mathrm{ml})$ was obtained to evaluate the progression of oocyte development. 148 DHP was injected into the ovarian tissue under anaesthesia (Palstra et al. 2005). Female eels ovulated 
14912 to 15 hours after DHP injection and at that time the eggs were stripped by applying gentle pressure

150 along the abdomen of the fish. The volume of ovulated eggs collected was recorded.

151 Induction of spermatogenesis in the male eels started 4 weeks after the induction of oogenesis in

152 females, as males only need 7-9 weeks of treatment to reach spermiation (Tomkiewicz et al. 2011).

153 Each week, males received an intramuscular injection of human chorionic gonadotropin (hCG, Sigma

154 Aldrich Denmark, A/S) at dose of $1.5 \mathrm{IU}$ hCG per kg initial body weight (Butts et al., 2014). An

155 additional hCG injection was given $12 \mathrm{~h}$ prior to milt collection in order to enhance sperm production.

\section{$156 \quad 2.4 \quad$ Sampling for gene expression and cytological analysis}

157 Sampling for each female comprised: 1) the $\sim 0.2 \mathrm{ml}$ ovarian biopsy obtained $\sim 1 \mathrm{~h}$ before the SPE

158 priming injection (SPE); 2) the $\sim 0.2 \mathrm{ml}$ biopsy obtained prior to DHP injection (DHP) and 3) a sample

159 of unfertilized eggs collected immediately after stripping (EGG). Each sample included digital images

160 of oocytes/eggs to measure lipid droplet diameter and a preserved sample ( $\sim .1 \mathrm{ml})$ for gene expression

161 analysis. Prior to photography, the sampled oocytes/eggs were cleared in Serra's liquid

162 (ethanol:formalin:acetic at 6:4:1, diluted 20X in phosphate buffered saline, PBS, see Stoeckel (2000))

163 for staining of the germinal vesicle. The pictures were taken at $20 \mathrm{X}$ magnification using a digital

164 camera (Digital Sight DS-Fi1, Nikon Corporation, Japan) connected to an optical microscope (Eclipse

165 55i, Nikon Corporation, Japan) for measurement of lipid droplet diameter inside the oocytes. Samples

166 taken for analysis of gene expression were preserved in RNA-later (Ambion Inc., Huntingdon, UK),

167 refrigerated at $5^{\circ} \mathrm{C}$ for $24 \mathrm{~h}$ and then frozen at $-20{ }^{\circ} \mathrm{C}$ until RNA extraction. 


\subsection{Fertilization rate, hatching success and larval survival}

169 In order to evaluate the egg viability, eggs were fertilized in vitro, and fertilization rate, hatching

170 success, and larval survival was determined. For each female, milt from 4-5 males was collected,

171 leaving three week intervals between individual male stripping. The spermatocrit was estimated

172 (pooled milt mixture according to Sørensen et al. (2013) and used to dilute milt in an immobilizing

173 diluent (Asturiano et al., 2004; Peñaranda et al., 2010). The diluted milt at a standardized concentration

174 was used for fertilization within 4 hours after collection (Butts et al., 2014).

175 Immediately after stripping, eggs were mixed with the milt solution and added natural seawater for

176 sperm activation (Butts et al. 2014). After 5 min gamete contact time, a sub-sample of eggs was

177 transferred to a $100 \mathrm{ml}$ graduated cylinder glass to estimate percent floating eggs. The remaining eggs

178 were transferred to $10 \mathrm{~L}$ containers for separation of floating and sinking eggs. The eggs were kept at

$17920{ }^{\circ} \mathrm{C}$ and the fertilization rate and floating percent was accessed 3-5 hours post fertilization (HPF). To

180 estimate fertilization success, a sample of 100-150 floating eggs was photographed using an optical

181 microscope (Eclipse 55i, Nikon Corporation, Japan) at 20X magnification and a digital camera (Digital

182 Sight DS-Fi1, Nikon Corporation, Japan). Fertilized eggs were identified by the presence of blastomere

183 cleavage (minimum 4 cell stage), while those that had not reached the 4-cell stage were considered

184 unfertilized.

185 For estimation of hatching success, eggs ( 200 eggs in triplicate, for each female) were collected from

186 the floating layer after 3-5 HPF and incubated at $20{ }^{\circ} \mathrm{C}$ in flasks (Nunc ${ }^{\circ} 75 \mathrm{~cm} 2$ flasks, non-treated

187 with ventilated caps, Thermo Scientific) (Sørensen et al. 2014). Each flask contained $250 \mathrm{ml}$ of

188 seawater $(36 \mathrm{ppt})$ ampicillin $(50 \mathrm{mg} / \mathrm{L})$ and rifampicin $(50 \mathrm{mg} / \mathrm{L})$. Flasks stayed undisturbed inside a

189 dark and closed incubator at $20{ }^{\circ} \mathrm{C}$ until the number of hatched larvae was counted at 55 HPF. To 
190 estimate larval survival, $300 \mathrm{~g}$ of eggs from the floating layer were incubated in a $60 \mathrm{~L}$ incubator with 191 natural seawater at $\sim 20^{\circ} \mathrm{C}$. After hatch, when available $\sim 3000$ larvae in triplicate were stocked in $40 \mathrm{~L}$ 192 tanks of an aquaculture recirculation system containing natural seawater adjusted to $36 \mathrm{ppt}$ salinity

193 using Tropic Marin Sea Salt and reared at $20{ }^{\circ} \mathrm{C}$. Survival was measured as the percentage of still 194 living larvae at 3 days post hatch (dph).

195 For statistical analysis, egg batches were categorized into two groups: i) high-quality and ii) low196 quality based on larval survival. Hereby, survival beyond the first 3 dph (high mortality period) was 197 used to differentiate the groups (Table 2).

$198 \quad 2.6 \quad$ Gene expression analysis

199 RNA extraction and cDNA synthesis:

200 After Proteinase K treatment, total RNA was purified from ovarian biopsies and ovulated eggs by 201 homogenization of $30 \mathrm{mg}$ of tissue in $700 \mu 1$ TRIzol reagent (Invitrogen Life Technologies, Carlsbad, 202 CA, USA). TRIzol/chloroform separation was performed to remove DNA and proteins. The aqueous203 phase was transferred to a new tube and $500 \mu \mathrm{l}$ of isopropanol were added for RNA precipitation. 204 Genomic DNA contamination was removed by treating the total RNA with the TURBO DNA-free kit 205 (Ambion). Total RNA quality and concentration was measured spectrophotometrically using 206 NanoDrop (Saveen Werner AB, Limhamn, Sweden).

207 RNA was then reverse transcribed into cDNA using Hight Capacity RNA-to-cDNA kit (AB) according 208 to manufacturer's protocol. In summary, reaction volumes of $20 \mu \mathrm{l}$ contained $450 \mathrm{ng}$ total RNA, 1X RT 209 buffer, $1 \mathrm{X}$ enzyme mix. The following cycling parameters were used: $37^{\circ} \mathrm{C}$ for $60 \mathrm{~min}, 95^{\circ} \mathrm{C}$ for 5 210 min and hold at $4{ }^{\circ} \mathrm{C}$, using a 2720 Thermal cycler, AB. 
211 Quantitative real-time PCR (qPCR):

212 The following gene specific primers were previously designed based on the nucleotide sequence of the 213 European eel: gonadotropin receptors, fshr, lhcgrl and lhcgr2 (Maugars and Dufour, 2015); estrogen 214 receptors, esr1, esr2a, esr2b, gpera and gperb (Lafont et al., 2016). Specific primers for European eel 215 18S ribosomal RNA gene (18S) were designed in this study (Table 1), and their specificity and 216 efficiency was tested in qPCR.

217 The qPCRs were performed with a lightcycler (Roche, Ltd. Basel, Switzerland), using SYBR Green I. 218 Each reaction was prepared with $4 \mu 1$ of diluted cDNA template, $2 \mu 1$ PCR grade water, $2 \mu 1$ of SYBR 219 Green master mix and $1 \mu 1$ of each forward and reverse primers ( 0.5 pmol each at final concentration).

220 The following qPCR conditions were applied: polymerase activation step of $10 \mathrm{~min}$ at $95{ }^{\circ} \mathrm{C}$, followed 221 by 51 cycles of $10 \mathrm{sec}$ of denaturizing at $95{ }^{\circ} \mathrm{C}, 5 \mathrm{sec}$ of annealing at $60{ }^{\circ} \mathrm{C}, 6 \mathrm{sec}$ of elongation at 72 $222{ }^{\circ} \mathrm{C}$ for esrl, esr2a, esr $2 b$, gpera and gperb or $10 \mathrm{sec}$ at $72{ }^{\circ} \mathrm{C}$ for $18 S$, lhcgrl, lhcgr 2 and $f s h r$. The 223 programs ended with a melting curve analysis by slowly increasing the temperature $\left(0.1^{\circ} \mathrm{C} / \mathrm{sec}\right)$ from $22465{ }^{\circ} \mathrm{C}$ to $95{ }^{\circ} \mathrm{C}$, with a continuous registration of changes in fluorescent emission intensity. This last 225 step aimed at ensuring the presence of only one amplified product. Each qPCR run contained a non226 template control (cDNA was substituted by water) for each primer pairs to confirm that the qPCR mix was not contaminated. Serial dilutions of a pool of ovary biopsies and ovulated egg cDNAs were used as a standard curve for each gene. One dilution was included in each run as a calibrator. Normalization of the qPCR data was performed using $18 S$ as a reference gene since it was stable through all sampling points with a coefficient of variance at SPE, DHP and OV of 40\%, 40\% and 48\%, respectively. 


\subsection{Measurement of lipid droplet diameter}

232 Using the digital images of each sample (before SPE priming, before DHP injection and ovulated 233 eggs), 10 oocytes were randomly selected among those at the most advanced stage of development. 234 Here, ten of the largest lipid droplets were measured using the free software ImageJ (1.48d) and the 235 maximum five values averaged (Unuma et al., 2011). For each lipid droplet, the diameter was 236 calculated by the average of two diameter measurements. At the final stages of coalescence, only a few 237 droplets became larger while the others became smaller (Fig. 1), in these stages, the diameter was 238 based on the diameter of the largest droplets only (Unuma et al., 2011).

\section{$239 \quad 2.8 \quad$ Statistical analysis}

240 Statistical analysis was performed using $\mathrm{R}$ version 3.1.3 ( $\mathrm{R}$ core team, 2015). Statistical differences in 241 gene expression and lipid droplet diameter between quality groups (high- and low-quality) in relation to 242 sampling time (before SPE, before DHP and after stripping) were evaluated using linear mixed-effects 243 (LME) models. The female ID was included in the models as within-subjects variable to account for 244 the repeated measurements taken on each female through the sampling points. Model assumptions of 245 normality and equal variance were checked using Q-Q plots and by observation of the residuals versus 246 fitted values plot. Square root and logarithmic transformations were applied to gene expression and 247 droplet diameter data whenever data deviated from a normal distribution. Linear regression analysis 248 was used to determine whether there were significant correlations between gene expression at each 249 sampling time and fertilization rate and hatching success. The expression of each gene was screened for 250 outliers using the Tukey's method. This method uses the interquartile range (IQR) to identify the 251 outliers range above and below the 1.5X IQR. A significance level $(p)$ of 0.05 was applied in all tests. 


\section{$252 \quad 3 \quad$ Results}

$253 \quad 3.1$ Egg production, fertilization and hatching success

254 The females studied produced on $327 \pm 152 \mathrm{~g}$ eggs corresponding to $29-56 \%$ of the initial body weight 255 (Table 2). The percent floating eggs varied from 25 to $100 \%$, while the fertilization rate ranged 256 between 15 to $99 \%$ and the hatching rate between 0 to $80 \%$. Batch size was positively related to initial 257 female body weight $(\mathrm{R}=0.94 ; p<0.001)$ and length $(\mathrm{R}=0.95 ; p<0.001)$. Fertilization rate was not 258 correlated with female length $(\mathrm{R}=-0.03 ; p=0.930)$ nor initial weight $(\mathrm{R}=0.09 ; p=0.798)$. Hatching 259 success ranged from 19 to $80 \%$ and 0 to $5 \%$ in the high- and low-quality groups, respectively (Table 260 2). There was also no significant correlation between hatching success and female length $(\mathrm{R}=-0.03 ; p$ $261=0.927)$ nor initial weight $(\mathrm{R}=0.05 ; p=0.901)$.

\section{$262 \quad 3.2$ Expression of gonadotropin receptors}

263 All three gonadotropin receptors $(f s h r$, lhcgr and $l h c g r 2)$ were detected in the ovarian biopsies with 264 genes differentially expressed across sampling points from the induction of oocyte maturation, SPE and 265 DHP, and EGG (Fig. 2). Overall, transcript levels of $f$ shr did not vary during oocyte maturation, i.e. 266 between the ovarian biopsy taken before SPE and the biopsy taken before DHP $(p>0.05)$. However, $267 f$ shr levels dropped down below the level of detection of qRT-PCR detection in the eggs (at least 534 268 times less expressed than in the ovarian biopsies). Within sampling points, the expression levels of $f$ shr were similar between the high- and low-quality groups in the biopsies obtained prior to SPE priming ( $p$ $>0.05$; Fig. 2). However, before DHP, $f s h r$ transcript levels were significantly lower in the high-quality group than in the low-quality group $(p<0.001)$. Present results also indicated a significant negative

272 correlation between $f$ sh $r$ before DHP injection and hatching success $(\mathrm{R}=-0.79 ; p=0.012$; Table 3$)$. 
273 Overall, lhcgrl mRNA levels did not vary significantly ( $p>0.05$ ) during maturation (from SPE to 274 DHP injection). In contrast, transcript levels were around 150 times lower in ovulated eggs than in the 275 ovarian biopsies $(p<0.001)$. Moreover, in the ovarian biopsies collected before SPE priming, lhcgrl 276 expression was significantly higher in the high-quality group compared to the low-quality ( $p$ $277=0.002$; Fig. 2). Present results also showed a significant positive correlation between lhcgrl at SPE 278 and hatching success $(\mathrm{R}=0.68, p=0.032$; Table 3$)$. There was no difference between the two groups 279 in the ovary samples taken before DHP injection and in ovulated eggs $(p>0.05)$.

280 Regardless of egg quality, lhcgr2 transcript levels were similar between the ovarian biopsies taken 281 before SPE and DHP ( $p>0.05$ ) but significantly less expressed in the ovulated eggs (at least 5 times 282 less expressed than in the ovarian biopsies, $p<0.001)$. Within sampling points, transcript levels of 283 ovarian lhcgr2 at SPE priming and DHP injection did not differ significantly between the high and low 284 quality groups ( $p>0.05$; Fig. 2). However, lhcgr2 mRNA levels in unfertilized egg samples were 285 significantly higher in the high-quality than in the low-quality group $(p=0.013)$. There were no 286 significant correlations between lhcgr2 transcript levels and hatching success or fertilization rate $(p>$ $287 \quad 0.05 ;$ Table 3).

\subsection{Expression of estrogen receptors}

289 The nuclear receptor esrl was expressed in the ovarian samples obtained during oocyte maturation 290 without significant variation between the ovarian samples before SPE priming and DHP $(p>0.05 ;$ Fig. 291 3). After stripping, transcript levels were below the level of detection of qRT-PCR in unfertilized eggs 292 (at least 40 times less expressed than in the ovarian biopsies). Moreover, esrl expression was similar 293 between the high- and low-quality groups within the SPE and DHP sampling points $(p>0.05)$. There 
294 were no significant correlations between esrl and hatching success or fertilization rate $(p>0.05$; Table $2953)$.

296 From the two nuclear esr2 receptors, only esr2a was detected in the ovary during the induction of 297 oocyte maturation. Irrespective of hatching success, transcript levels of esr2a did not vary during 298 maturation treatment $(p>0.05)$, but the gene was much less expressed in unfertilized eggs (at least 67 299 times less expressed than in the ovarian biopsies, $p<0.001)$. In the biopsies taken before SPE priming, 300 transcript levels of esr2a were significantly higher in the high-quality group compared to the low301 quality group ( $p=0.020$; Fig. 3). In the ovarian biopsies taken before DHP and ovulated eggs, esr $2 a$ 302 expression levels were similar between groups $(p>0.05)$. We did not find any significant correlations 303 between esr $2 a$ transcript levels and hatching success or fertilization rate $(p>0.05$; Table 3$)$. Transcript 304 levels of esr $2 b$ were below the qRT-PCR detection threshold in all samples and could not be measured.

305 The two estradiol membrane receptors, gpera and gperb, were detectable and presented a different 306 expression pattern during induced oocyte maturation and after stripping (Fig. 3). Irrespective of egg 307 quality group, gpera transcript levels did not vary during maturation treatment $(p>0.05)$ but were 308 significantly lower in the eggs $(p<0.001)$. Expression of gpera did not differ significantly between 309 high- and low-quality in neither the ovarian biopsies before SPE and DHP injection, nor in ovulated 310 eggs ( $p>0.05$; Fig. 3). There were no significant correlations between gpera transcript levels and 311 hatching success or fertilization rate $(p>0.05$; Table 3$)$. Overall, there was no significant difference in 312 gperb mRNA expression levels during maturation $(p>0.05)$ while transcript levels of gperb dropped 313 to a level below the qRT-PCR detection threshold in ovulated eggs (at least 375 times less expressed 314 than in the ovarian biopsies). The expression levels of gperb before SPE administration did not differ 315 between the high-quality and low-quality group $(p>0.05)$ while levels were significantly lower in the 
316 high-quality before the DHP administration ( $\mathrm{p}=0.010$; Fig. 3). Present results did not show any 317 significant correlations between gperb levels and hatching success or fertilization rate $(\mathrm{P}>0.05$; Table $3183)$.

\section{$3193.4 \quad$ Lipid-droplet related oocyte maturation status}

320 Image analysis of the ovarian biopsies collected during the course of oocyte maturation induction 321 revealed 2-3 cohorts of oocytes of different sizes and stages of development (Fig. 4). Oocytes at the 322 most advanced stage of development were at the germinal vesicle migration stage, characterized by a 323 and $248 \pm 74 \mu \mathrm{m}$ at EGG. Overall, mean lipid droplet diameter was significantly higher and with wide

size variations in the low-quality than in the high-quality group ( $p=0.028$; Fig. 5), and mean size increased significantly over time in both groups (from SPE to EGG, $p<0.001$ ). Lipid droplet size in the low-quality group also demonstrated an increasingly larger inter-female size variation over time, compared to the high-quality group, where there were less lipid droplet size variation at all times. We did not find a significant difference in droplet diameter between high- and low-quality at SPE priming ( $p>0.05$ ) but at DHP and EGG, lipid droplet diameter was significantly higher in the low-quality group $(p=0.042$ and $\mathrm{p}=0.005$, respectively). 


\section{Discussion}

339 4.1 Differential expression of gonadotropin receptors

340 Gonadotropin receptors mediate the biological effects exerted by gonadotropin hormones. In this study, 341 we analyzed for the first time the expression pattern of the $f$ shr and the duplicate lhcgr during the 342 induction of follicular maturation and ovulation of European eel using SPE treatment. The expression 343 of the two genes encoding distinct LHCGR (lhcgrl and lhcgr2) was also detected in the ovary of 344 immature eels (Maugars and Dufour, 2015). In the present case, both lhcgrl and lhcg2 were well 345 expressed in the ovary during induced maturation. Since the report of the coexistence of duplicated 346 lhcgr in teleosts (Maugars and Dufour, 2015), their expressions have not yet been compared in any 347 other teleost species. In fishes, there are few studies about the expression of gonadotropin receptors 348 during follicular maturation and ovulation and none concerning gonadotropins and estradiol receptors 349 multiple paralogs. A previous study showed a high expression of ovarian lhcgr orthologous to eel 350 lhcgr2, in mature female Atlantic salmon (Salmo salar) caught during the upstream migration 351 (Maugars and Schmitz, 2006), which appears characteristic of the maturation stage prior to ovulation. 352 Moreover, we found that both genes were significantly less expressed in ovulated eggs. This agrees 353 with the location of LH binding sites found in the granulosa and thecal cells in European eel (Salmon et 354 al., 1988). Similarly, lhcgr orthologous to eel lhcgrl was found to be expressed in granulosa and 355 weakly in theca cells in chub mackerel (Scomber japonicus) (Nyuji et al., 2013) and Atlantic halibut 356 (Hippoglossus hippoglossus) (Kobayashi et al., 2008). Therefore, a drop in mRNA levels would be 357 expected in successfully ovulated eggs due to the loss of the follicle layers that remain inside the ovary 358 after the oocyte is extruded. Nevertheless, the drop in expression in ovulated eggs was more substantial 359 for lhcgrl (150 less expressed) than for lhcgr2 (5 times less expressed), suggesting that lhcgrl is 360 mostly expressed in follicular cells. 
361 We hypothesized that differences in responsiveness to hormonal treatments during oocyte maturation 362 may be related to differences in hormone receptor expression, which consequently could affect 363 embryonic development. To test this, we calculated hatching success and larval survival as measures of 364 embryonic developmental competence (egg quality). Transcript levels of lhcgr2 during induction of 365 oocyte maturation were similar regardless of hatching success. However, lhcgr2 mRNA in ovulated 366 eggs was significantly higher in the high-quality group when compared to the low-quality group, 367 suggesting that $l$ chgr 2 could have a role in embryonic development. Gonadotropin receptor transcripts are also present in mouse oocyte and preimplantation embryo, with a potential beneficial role in oocyte maturation and early embryonic development (Patsoula et al., 2001).

Previous studies have shown that gonadotropic treatment induces an increase in mRNA levels of $\operatorname{lh} \beta$ as well as an increase in LH hormone in the pituitary in both European (Dufour et al., 1989; Schmitz et al., 2005) and Japanese eel (Nagae et al., 1996; Saito et al., 2003; Jeng et al., 2007). This increase in pituitary content of LH is likely necessary for the LH surge (in this case mimicked by the LH present in the SPE) triggering ovulation. However, it is still uncertain if this observation is due to the effect of gonadotropins alone, as both SPE and CPE treatments contain other components (neurotransmitters, steroids) that can affect receptor expression. Our results showed that ovarian levels of lhcgrl at the time of SPE primer administration were both positively correlated with hatching success, and were significantly higher in the high-quality group than in the low-quality group at SPE. This suggests that 379 females with higher hatching success had higher sensitivity to LH at the time SPE was administrated. 380 In contrast, the significantly lower levels of lhcgrl expression in females with low-quality eggs could 381 have limited their response to the LH in the SPE primer. This is particularly important, in a first stage 382 of oocyte maturation, LH regulates the follicle's ability to produce maturation-inducing steroid (MIS) 
and the oocyte's response to MIS (i.e. oocyte maturational competence); on a second stage the follicle 384 cells produce MIS (Patiño et al., 2001). Thus, failure to respond to LH at the first stage could 385 subsequently compromise the oocyte's ability to respond to the MIS (i.e. the DHP injection). 386 Additionally, LH signalling can stimulate other pathways than those leading to DHP synthesis. This has 387 been observed in zebrafish, where the expression of ptgs $2 a$ (a cox-2 gene) induced by LH was 388 necessary for ovulation to occur (Tang et al., 2017). Since oocyte maturation and ovulation may be 389 independently/differently regulated by the same ligand, the two processes may come out of synchrony with each other, and this may influence the developmental capacity of the egg/embryo. In this case, the mismatch between lhcgrl expression and the administration of the SPE primer may have affected the follicle's ability to respond to DHP in females in the low-quality group. Hence, a high expression of lhcgrl before SPE priming seems to be a good biomarker of high maturational competence.

394 Overall, $f s h r$ was well expressed in the mature ovary at all sampling times during the induction of 395 oocyte maturation. In Japanese eel, 17 weeks of treatment with pituitary homogenates also increased ovarian levels of $f s h r$ (Jeng et al., 2007). However, the physiological relevance of high $f s h r$ expression during ovarian maturation in teleosts is still unclear. In the case of the eel, gonadotropins contained in exogenous pituitary homogenates (SPE in this case) could up-regulate the expression of both gonadotropin receptors. Alternatively, in the case of multiple spawning, an ovulatory surge of FSH could play an important role in the follicle recruitment for the next reproductive cycle (Prat et al., 1996; 401 Tyler et al., 1997; Sambroni et al., 2007). In this study, oocyte development presented a groupsynchronous pattern (Wallace and Selman, 1981), with 2-3 cohorts of oocytes of different size and stage of development present in the ovarian biopsies taken during the induction of oocyte maturation 
regulatory role of FSH on the less developed oocyte batches also present in the biopsies. Alternatively, it is also possible that FSHR has an important function on maturing oocytes (as occurs in mammals, where FSH up-regulates LHCGR (Zeleznik et al., 1974). After ovulation, levels of $f$ shr mRNA level dropped below the level of detection, indicating that $f s h r$ is also mostly expressed in the follicle cells surrounding the oocyte. This is in agreement with the observations by in situ hybridization of $f$ shr expression in granulosa and theca cells in vitellogenic follicles in salmon (Andersson et al., 2009).

In relation to hatching success, present results showed that transcript levels of $f s h r$ before the DHP injection were negatively correlated with hatching success, and females with low quality eggs had significantly higher transcript levels of $f s h r$. This indicates that females in the low-quality group were more sensitive to FSH at the time DHP was administrated. However, while $\operatorname{lh} \beta$ mRNA levels tend to increase, $f_{s h} \beta$ levels significantly decrease with gonadotropic treatment in both Japanese (Yoshiura et al., 1999) and European eel females (Schmitz et al., 2005). Therefore, increased sensitivity to FSH at the time of DHP injection does not appear to be determinant for successful oocyte maturation and ovulation treatment in European eel. In contrast, increasing mRNA levels of $f s h r$ were associated to a better competence of the oocyte to mature following pituitary hormone induction in rainbow trout (Oncorhynchus mykiss) (Bobe et al., 2003). However, differences in hormone receptor expression among species are likely influenced by differences in the reproductive strategies. For example, in rainbow trout which is considered as total spawner (Mylonas and Zohar, 2007), fshr mRNA levels peak at maturation and ovulation while lhcgr increased significantly later after ovulation (Sambroni et al., 2007). In contrast, in zebrafish, which is a multiple batch spawner, $f s h r$ transcripts peaked at midvitellogenesis and dropped at the end of vitellogenesis (Kwok et al., 2005). Overall, a combination of low expression of ovarian lhcgrl before SPE priming and high expression of $f$ shr, when DHP is 
427 administrated, could be indicators of an ineffective response to oocyte maturation treatment resulting in 428 low egg quality.

\section{$429 \quad 4.2$ Differential expression of estrogen receptors}

430 In this study, we quantified gene expression of three nuclear (esr 1, esr $2 a$, esr $2 b$ ) and two membrane 431 (gpera and gperb) estrogen receptors, during hormonal induction of oocyte maturation in European eel.

432 We found that transcripts of esrl were quite similar in the eel ovary throughout induced maturation, 433 with no significant differences between the two hatching groups. This suggests that esrl mRNA is not 434 a limiting factor for the development of maturational competence. Nevertheless, up-regulation of esrl 435 transcripts in the ovary of matured eels after ovulation (Lafont et al, 2015) suggests that this receptor 436 might play an important role during oocyte maturation. Regulation of esrl transcript levels may be 437 associated with an increase in circulatory levels of estradiol-17 $\beta\left(\mathrm{E}_{2}\right)$ during oocyte maturation stages 438 (da Silva et al., 2016). In particular, $\mathrm{E}_{2}$ plasma concentration increases two to five times after SPE 439 priming in European eel (H. Tveiten, unpubl. results). Up-regulation of esrl was associated with an 440 increase of circulatory estrogens before ovulation also in vitro in eel hepatocytes (Lafont et al, 2015). 441 In contrast, esrl expression in the testis of male eels was markedly expressed in early stages of 442 spermatogenesis but significantly down-regulated in late stages of spermatogenesis (Morini et al., 443 2017). This indicates a differential expression pattern of esrl between oogenesis and spermatogenesis 444 in eels. Differences in hepatic esrl expression between sexes have been observed in goldfish and are 445 likely related to differences in basal levels of $\mathrm{E}_{2}$ between males and females (Nelson and Habibi, 2010). 446 In unfertilized eggs, esrl transcript levels were below the level of detection, suggesting that this 447 estrogen receptor is mostly expressed in the follicular cells. 
448 Before SPE priming, esr2a transcripts were significantly more expressed in females with higher 449 hatching success which may indicate that this receptor has an important role during oocyte maturation. 450 In previous studies, the expression of esr2a in mature female eels after spawning was similar to 451 controls (Lafont et al., 2015) and in male eels, it was down-regulated during final stages of 452 spermatogenesis (Morini et al., 2017). Transcripts of esr2a were below the level of detection of the 453 qRT-PCR in ovulated eggs, suggesting that they are mainly expressed in follicular cells, as esrl. 454 Transcripts of $e s r 2 b$ were below the level of detection of the qRT-PCR in all samples, i.e. undetectable 455 during follicular maturation and ovulation. In male eels, esr $2 b$ transcripts in the testis were significantly 456 down-regulated throughout spermatogenesis (Morini et al., 2017). Thus, it is likely that esr2b does not 457 play a key role during the final stages of gametogenesis in European eel.

458 It is well known that in female fish GPER mediates the $E_{2}$-induced meiotic arrest of oocytes, e.g. 459 zebrafish, Atlantic croaker and common carp (Majumder et al., 2015; Pang and Thomas, 2009; Pang et 460 al., 2008; Peyton and Thomas, 2011). In these previous studies, only one GPER gene was 461 characterized, known now to be the orthologous to teleost gpera. We found that gpera transcripts were 462 expressed at similar levels in the ovary throughout the oocyte maturation (all stages), without 463 significant differences between the high-quality and low-quality group. Levels of gpera transcript 464 showed only a moderate decrease in ovulated eggs (not significant), indicating that gpera transcripts 465 are largely present in the eel oocyte itself, in contrast to all the other estradiol receptors. In contrast, 466 expression of gperb before DHP injection was significantly lower in females exhibiting higher egg 467 viability. Furthermore, gperb was the only estrogen receptor that was less expressed in females 468 exhibiting high quality eggs. This may suggest that gperb plays an important role in mediating the 469 inhibitory effect of estrogen during oocyte maturation also in European eel, where estrogen-dependent 
470 oocyte growth is arrested at the first meiotic prophase by high levels of intracellular cyclic AMP 471 (cAMP) (Conti et al., 2002). In the pre-ovulatory phase, a LH surge causes a shift in the steroidogenic 472 pathway to the production of the MIS. When the MIS production (DHP injection in this case) is 473 sufficient to overcome the estrogen inhibitory effect, the binding of MIS to a G protein-coupled 474 progestin membrane receptor triggers meiosis resumption and GVBD by causing a decrease in cAMP 475 concentrations (Jalabert and Finet 1986; Finet et al., 1988). Moreover, in Japanese eel, increased $E_{2}$ in 476 the late stages of oocyte development inhibits the production of DHP (Ijiri et al., 1995). Thus, a lower 477 expression of gperb in the HEQ group suggests a lower sensitivity to estrogen and subsequently a 478 lower estrogen inhibition, which may have enhanced the effect of DHP. In male eels, both gpera and 479 gperb transcripts significantly increased during spermatogenesis suggesting that GPERs may be 480 involved in final sperm maturation (Morini et al., 2017). Overall, our results raise the possibility that an $481 \mathrm{E}_{2}$ pathway, possibly regulated by esr2a and gperb, is involved in the control of oocyte maturation also 482 in European eel. However, we did not find any significant correlation between the expression of these 483 two genes and other egg quality indicators such as fertilization and hatching success. Thus, evidence is 484 weak and further investigation is necessary to clarify their role during oocyte maturation and 485 subsequent egg quality.

\subsection{Cytological indicators of oocyte maturation status}

487 An early index of maturational acquisition is the onset of germinal vesicle migration, which is 488 accompanied by the rise in LH at the end of follicle growth (Lubzens et al., 2010). In this study, a 489 peripheral germinal vesicle in the most advanced oocytes was used as an indicator that females had 490 progressed into initial stages of oocyte maturation before SPE priming. The appearance of oil droplets 491 was used as a marker of the maturation progress to initiate SPE priming or DHP injection (Palstra et al. 
492 2005; Unuma et al., 2011). Here, the coalescence of the oil droplets reflects the hormonal processes 493 during final maturation resulting in decreasing numbers and increasing size of the lipid droplets. 494 Interestingly in this study, the oocytes of females in the high-quality group had on average smaller lipid 495 droplets with less size variation compared to those with low-quality group. Especially at DHP and 496 ovulation the difference between the groups was significant. The observed variation in lipid droplet 497 size, in conjunction with the hormone receptor expression pattern in the same females, suggests that 498 treatment administrated at an earlier stage enhanced maturational competence and the subsequent 499 developmental capacity of the egg/embryo. In general, limited information is available on the 500 mechanisms of oocyte lipid coalescence as well as on the role of this physiologically important process 501 in the subsequent survival and development of the eggs and embryos. Our findings, substantiating 502 insight in the underlying hormonal processes, suggest lipid droplet diameter to be an accurate, 503 quantitative indicator of maturation status in European eel.

504 In conclusion, ovarian $f$ shr, lhcgrl, esr $2 a$ and gperb were differentially expressed across sampling 505 points between females presenting high and low egg quality. A mismatch between the timing of 506 hormone injections and the expression of some of these genes may therefore influence the follicle's 507 ability to respond to treatment. Furthermore, changes in hormone receptor expression were associated 508 with changes in oocyte maturation status. Here, the average size of lipid droplets in advanced oocytes 509 was smaller in the high- compared to low-quality group throughout the maturation process, indicating 510 that the timing of hormonal treatments can be optimized, thereby optimizing procedures in assisted 511 reproduction of the endangered European eel. 


\section{Acknowledgements}

513 We thank P. Lauesen, Billund Aquaculture Service, C. Graver, Danish Aquaculture Organisation, and 514 M. Krüger-Johnsen, Technical University of Denmark, for their assistance conducting experiments and 515 sampling, H. Johnsen, Nofima, for laboratory assistance, and A. Nielsen for guidance on statistical 516 methods. This work was supported by the European Commission's $7^{\text {th }}$ Framework Programme (Grant 517 number 245257: Reproduction of European Eel: Towards a self-sustained Aquaculture, PRO-EEL) and 518 Innovation Fund Denmark (Grant number 11-2013-3: Eel Hatchery Technology for a Sustainable 519 Aquaculture (EEL-HATCH)), and a travel grant from the European Cooperation in Science and 520 Technology (COST, Grant number FA1205: AQUAGAMETE) to the first author in order to perform 521 gene expression studies at BOREA, France.

\section{References}

523 Andersson, E., Nijenhuis, W., Male, R., Swanson, P., Bogerd, J., Taranger, G.L., Schulz, R.W., 2009. 524 Pharmacological characterization, localization and quantification of expression of gonadotropin 525 receptors in Atlantic salmon (Salmo salar L.) ovaries. Gen. Comp. Endocrinol. 163, 329-339.

526 Asturiano, J.F., Pérez, L., Garzón, D.L., Marco-Jiménez, F., Peñaranda, D.S., Vicente, J.S., Jover, M., 527 2004. Physio-chemical characteristics of seminal and development of media and methods for the 528 cryopreservation of European eel sperm. Fish. Physiol. Biochem. 30, 283-293.

529 Bobe, J., Maugars, G., Nguyen, T., Rime, H., Jalabert, B., 2003. Rainbow trout follicular maturational 530 competence acquisition is associated with an increased expression of follicle stimulating hormone receptor and insulin-like growth factor 2 messenger RNAs. Mol. Reprod. Dev. 66, 46-53.

Butts, I.A.E., Sørensen. S.R., Politis, S.N., Pitcher, T.E., Tomkiewicz, J., 2014. Standardization of fertilization protocols for the European eel, Anguilla anguilla. Aquaculture 426-427, 9-13.

Butts, I.A.E., Sørensen. S.R., Politis, S.N., Tomkiewicz, J., 2016. First-feeding by European eel larvae: A step towards closing the life cycle in captivity. Aquaculture 464, 451-458. 
536 Chauvigné, F., Zapater, C., Gasol, J.M., Cerdà, J., 2014. Germ-line activation of the luteinizing hormone receptor directly drives spermiogenesis in a nonmamalian vertebrate. Proc. Natl. Acad. Sci. U.S.A. 111, 1427-1432.

Conti, M., Andersen, C.B., Richard, F., Mehats, C., Chun, S.Y., Horner, K., Jin, C., Tsafriri, A., 2002. Role of cyclic nucleotide signaling in oocyte maturation. Mol. Cell. Endocrinol. 187, 153-159.

da Silva, F.F.G., Støttrup, J.G., Kjørsvik, E., Tveiten, H., Tomkiewicz, J., 2016. Interactive effects of dietary composition and hormonal treatment on reproductive development of cultured females eel, Anguilla anguilla. Anim. Reprod. Sci. 171, 17-26.

Dufour S, Delerue-Le Belle N, Baloche, S., Fontaine Y.A., 1989. Positive feedback control by the gonads on gonadotropin $(\mathrm{GTH})$ and gonadoliberin $(\mathrm{GnRH})$ levels in experimentally matured female silver eels, Anguilla anguilla. Fish. Physio. Biochem. 7, 157-162.

Dufour S, Delerue-Le Belle N, Fontaine Y.A., 1983. Development of a heterologous radioimmunoassay for eel (Anguilla anguilla) gonadotropin. Gen. Comp. Endocrinol. 49, 404413.

Dufour S., Lopez E., Le Menn F., Delerue-Le Belle N., Baloche S., Fontaine Y.A., 1988. Stimulation of gonadotropin release and ovarian development, by the administration of a gonadoliberin agonist and of dopamine antagonists, in female silver eel pretreated with estradiol. Gen. Comp. Endocrinol. 70, 20-30.

Falkenstein, E., Tillmann, H.C., Christ, M., Feuring, M., Wehling, M., 2000. Multiple actions of steroid hormones - a focus on rapid, nongenomic effects. Pharmacol. Rev. 52, 513-556.

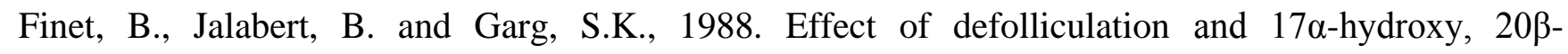
dihydroprogesterone on cyclic AMP level in full-grown oocytes of the rainbow trout, Salmo gairdneri. Gamete Res. 19, 241-252.

Fontaine, M., Bertrand, E., Lopez, E, Callamand, O., 1964 Sur la maturation des organes Génitaux de l'Anguille femelle (Anguilla anguilla L.) et l'émission spontanée des æufs en aquarium. C. R. Acad. Sci. 259, 2907-2910.

Hawkins, M.B., Thornton, J.W., Crews, D., Skipper, J.K., Dotte, A., Thomas, P., 2000. Identification of a third distinct estrogen receptor and reclassification of estrogen receptors in teleosts. Proc. Natl. Acad. Sci. USA 97, 10751-10756. 
Ijiri, S., Kazeto, Y., Takeda, N., Chiba, H., Adachi, S., Yamauchi, K., 1995. Changes in serum steroid hormones and steroidogenic ability of ovarian follicles during artificial maturation of cultivated Japanese eel Anguilla japonica. Aquaculture 135, 3-16.

Jalabert, B., Finet, B., 1986. Regulation of oocyte maturation in the rainbow trout, Salmo gairdneri: role of cyclic AMP in the mechanism of action of the maturation inducing steroid (MIS), 17 $\alpha$ hydroxy, 20ß-dihydroprogesterone. Fish. Physiol. Biochem. 2, 65-74.

Jeng, S.R., Yueh, W.S., Chen, G.R., Lee, Y.H., Dufour, S., Chang, C.F., 2007. Differential expression and regulation of gonadotropins and their receptors in the Japanese eel, Anguilla japonica. Gen. Comp. Endocrinol. 154, 161-173.

Kagawa, H., Sakurai, Y., Horiuchi, R., Kazeto, Y., Gen, K., Imaizumi, H., Masuda, Y., 2013. Mechanism of oocyte maturation and ovulation and its application to seed production in the Japanese eel. Fish Physiol. Biochem. 39, 13-17.

Kagawa, H., Tanaka, H., Ohta, H., Unuma, T., Nomura, K., 2005. The first success of glass eel production in the world: basic biology on fish reproduction advances new applied technology in aquaculture. Fish Physiol. Biochem. 31, 193-199.

Kazeto Y, Kohara M, Tosaka R, Gen K, Yokoyama M, Miura C, Miura, T., Adachi, S., Yamauchi, K., 2012. Molecular characterization and gene expression of Japanese eel (Anguilla japonica) gonadotropin receptors. Zool. Sci. 29, 204-211.

Kobayashi, T., Pakarinen, P., Torgersen, J., Huhtaniemi, I., Andersen, Ø., 2008. The gonadotropin receptors FSHR and LH-R of Atlantic halibut (Hippoglossus hippoglossus) -2. Differential follicle expression and asynchronous oogenesis. Gen. Comp. Endocrinol. 156, 595-602.

Kwok, H.F., So, W.K., Wang, Y., Ge, W., 2005. Zebrafish gonadotropins and their receptors: I. Cloning and characterization of zebrafish follicle-stimulating hormone and luteinizing hormone receptors- evidence for their distinct functions in follicle development. Biol. Reprod. 72, 13701381.

Lafont, A.-G., Rousseau, K., Tomkiewicz., Dufour, S., 2016. Three nuclear and two membrane estrogen receptors in basal teleosts, Anguilla sp.: Identification, evolutionary history and differential expression regulation. Gen. Comp. Endocrinol. 235, 177-191. 
593 Lokman, P.M., Detlef, H.R., Davie, P.S., Young, G., 2003. The physiology of silvering in Anguillid

594

595

596

597

598

599

600

601

602

603

604

605

606

607

608

609

610

611

612

613

614

615

616

617

618

619

620

621

622 eels: androgens and control of metamorphosis from the yellow to silver stage. In: K. Aida, K. Tsukamoto \& K. Yamauchi (Eds.), Eel Biology, pp. 331-349. Springer Verlag, Tokyo.

Lubzens, E., Bobe, J., Young, G., Sullivan, C.V., 2017. Maternal investment in fish oocytes and eggs: The molecular cargo and its contributions to fertility and early development. Aquaculture 472, 107-143.

Lubzens, E., Young, G., Bobe, J., Cerdà, J., 2010. Oogenesis in teleost: How fish eggs are formed. Gen. Comp. Endocrinol. 165, 367-389.

Ma, C.H., Dong, K.W., Yu, K.L., 2000. cDNA cloning and expression of a novel estrogen receptor $\beta$ subtype in goldfish (Carassius auratus). Biochim. Biophys. Acta 1490, 145-152.

Majumder, S., Das, S., Moulik, S.R., Mallick, B., Pal, P., Mukherjee, D., 2015. G-protein coupled estrogen receptor (GPER) inhibits final oocyte maturation in common carp, Cyprinus carpio. Gen. Comp. Endocrinol. 211, 28-38.

Maugars, G., Dufour, S., 2015. Demonstration of the Coexistence of Duplicated LH Receptors in Teleosts, and Their Origin in Ancestral Actinopterygians. Plos one 10(8), e0135184.

Maugars, G., Schmitz, M., 2006. Molecular cloning and characterization of FSH and LH receptors in Atlantic salmon (Salmo salar L.). Gen. Comp. Endocrinol. 149, 108-117.

Menuet, A., Pellegrini, E., Anglade, I., Blaise, O., Laudet, V., Kah, O., Pakdel, F., 2002. Molecular characterization of three estrogen receptor forms in Zebrafish: binding characteristics, transactivation properties, and tissue distributions. Biol. Reprod. 66, 1881-1892.

Morini, M., Peñaranda, D.D., Vílchez, M.C., Tveiten, H., Lafont, A.G., Dufour, S., Pérez, L., Asturiano, J.F., 2017. The expression of nuclear and membrane estrogen receptors in the European eel throughout spermatogenesis. Comp. Biochem. Physiol. A 203, 91-99.

Mosselman, S., Polman, J., Dijkema, R., 1996. ER beta: identification and characterization of a novel human estrogen receptor. FEBS Lett. 392, 49-53.

Mylonas, C.C., Fostier, A., Zanuy, S., 2010. Broodstock management and hormonal manipulations of fish reproduction. Gen. Comp. Endocrinol. 165, 516-534.

Mylonas, C.C., Zohar, Y., 2007. Promoting oocyte maturation, ovulation and spawning in farmed fish. In: Babin, P.J., Cerdà, J., Lubzens, E. (Eds.), The fish oocyte: from basic studies to biotechnological applications. Springer, Dordrecht, The Netherlands. pp. 437-474. 
623 Nagae, M., Todo, T., Gen, K., Kato, Y., Young, G., Adachi, S., Yamauchi, K., 1996. Molecular cloning 624 of the cDNAs encoding pituitary glycoprotein hormone alpha- and gonadotropin II beta-subunits 625 626 of the Japanese eel, Anguilla japonica, and increase in their mRNAs during ovarian development induced by injection of chum salmon pituitary homogenate. J. Mol. Endocrinol. 16, 171-181.

Nagler, J.J., Cavileer, T., Sullivan, J., Cyr, D.G., Rexroad, C., 2007. The complete nuclear estrogen receptor family in the rainbow trout: discovery of the novel ER $\alpha 2$ and both ER $\beta$ isoforms. Gene 392, 164-173.

Nelson, E.R., Habibi, H.R., 2010. Functional significance of nuclear estrogen receptor subtypes in the liver of goldfish. Endocrinology 151, 1668-1676.

Norman, A.W., Mizwicki, M.T., Norman, D.P., 2004. Steroid-hormone rapid actions, membrane receptors and a conformational ensemble model. Nat. Rev. Drug Discovery 3, 27-41.

Nyuji, M., Kitano, H., Shimizu, A., Lee, J.M., Kusakabe, T., Yamaguchi, A., Matsuyama, M., 2013.

Ohta, H., Kagawa, H., Tanaka, H., Okuzawa, K., Hirose, K., 1996. Changes in fertilization and 639 hatching rates with time after ovulation induced by 17, 20ß-dihydroxy-4-pregnen-3-one in the Japanese eel, Anguilla japonica. Aquaculture 139, 291-301. Matsuyama M. Characterization, localization, and stage-dependent gene expression of gonadotropin receptors in chub mackerel (Scomber japonicus) ovarian follicles. Biol Reprod. 88, 148.

Ohta, H., Kagawa, H., Tanaka, H., Okuzawa, K., Linuma, N., Hirose, K., 1997. Artificial induction of maturation and fertilization in the Japanese eel, Anguilla japonica. Fish Physiol. Biochem. 17, 163-169.

Palstra, A.P., Cohen, E.G.H., Niemantsverdriet, P.R.W., van Ginneken, V.J.T., van den Thillart, G.E.E.J.M., 2005. Artificial maturation and reproduction of European silver eel: development of oocytes during final maturation. Aquaculture 249, 533-547.

Pang, Y., Dong, J., Thomas, P., 2008. Estrogen signaling characteristics of Atlantic croaker G proteincoupled receptor 30 (GPR30) and evidence it is involved in maintenance of oocyte meiotic arrest. Endocrinol. 149, 3410-3426.

Pang, Y., Thomas, P., 2009. Involvement of estradiol-17 $\beta$ and its membrane receptor, G protein coupled receptor 30 (GPR30) in regulation of oocyte maturation in zebrafish, Danio rario. Gen. Comp. Endocrinol. 161, 58-61. 
653 Patiño, R., Yoshizaki, G., Thomas, P., Kagawa, H., 2001. Gonadotropic control of ovarian follicle 654 maturation: the two-stage concept and its mechanisms. Comp. Biochem. Physiol. 129, 427-439.

655 Patsoula E.,Loutradis D., Drakakis P., Kallianidis K., Bletsa R. Michalas S., 2001. Expression of 656 mRNA for the LH and FSH receptors in mouse oocytes and preimplantation embryos. 657 Reproduction. 121, 455-461.

658 Pedersen, B.H., 2003. Induced sexual maturation of European eel Anguilla anguilla and fertilisation of 659 the eggs. Aquaculture. 224, 323-338.

660 Pedersen, B.H., 2004. Fertilization of eggs, rate of embryonic development and hatching following 661 induced maturation of the European eel Anguilla anguilla. Aquaculture 237, 461-473.

662 Peñaranda, D.S., Pérez, L., Gallego, V., Barrera, R., Jover, M., Asturiano, J.F., 2010. European Eel 663 Sperm Diluent for Short-term Storage. Reprod. Domest. Anim. 45, 407-415.

664 Peyton, C., Thomas, P., 2011. Involvement of epidermal growth factor receptor signaling in estrogen 665 inhibition of oocyte maturation mediated through the $G$ protein-coupled estrogen receptor (Gper) 666 in zebrafish (Danio rerio), Biol. Reprod. 85, 42-50.

667 Pierce J, Parsons TF., 1981. Glycoprotein hormones: structure and function. J. Annu. Rev. Biochem. $668 \quad 50,465-495$.

669 Prat, F., Sumpter, J.P., Tyler, C.R., 1996. Validation of radioimmunoassays for two salmon 670 gonadotropins (GTH I and GTH II) and their plasma concentrations throughout the reproductive 671 cycle in male and female rainbow trout (Oncorhynchus mykiss). Biol. Reprod. 54, 1375-1382.

672 Revankar, C.M., Cimino, D.F., Sklar, L.A., Arterburn, J.B., Prossnitz, E.R., 2005. A transmembrane 673 intracellular estrogen receptor mediates rapid cell signaling. Science 307, 1625-1630.

674 Rosenfeld, H., Meiri, I., Elizur, A., 2007. Gonadotropic regulation of oocyte development. In: Babin, 675 P.J., Cerdà, J., Lubzens, E. (Eds.), The Fish Oocyte: From Basic Studies to Biotechnological 676 Applications. Springer, Dordrecht, The Netherlands, pp. 175-202.

677 Saito, K., Lokman, P.M., Young, G., Ozaki, Y., Matsubara, H., Okumura, H., Kazeto, Y., Yoshiura, Y., 678 Aida, K., Adachi, S., Yamauchi, K., 2003. Follicle-stimulating hormone $\beta$, luteinizing hormone $679 \beta$, and glycoprotein hormone $\alpha$ subunit mRNA levels in artificially maturing Japanese eel 680 Anguilla japonica and naturally maturing New Zealand long-finned eel Anguilla dieffenbachia. $681 \quad$ Fish. Sci. 69, 146-153. 
682 Salmon, C., Nunez-Rodriguez, J., Marchelidon, J., Le Menn, F., Fontaine, Y.A., 1988. Gonadotropin 683 binding sites in eel ovary: Autoradiographic visualization and new data on specificity. Reprod. $684 \quad$ Nutr. Dévelop. 28, 1165-1175.

685 Sambroni, E., Le Gac, F., Breton, B., Lareyre, J.J., 2007. Functional specificity of the rainbow trout 686 (Oncorhynchus mykiss) gonadotropin receptors as assayed in a mammalian cell line. J. 687 Endocrinol. 195, 213-228.

688 Schmitz, M., Aroua, S., Vidal, B., Le Belle, N., Elie, P., Dufour, S., 2005. Differential regulation of 689 luteinizing hormone and follicle-stimulating hormone expression during ovarian development 690 and under sexual steroid feedback in the European eel. Neuroendocrinology 81, 107-119.

691 Sørensen, S.R., Gallego, V., Pérez, L., Butts, I.A.E., Tomkiewicz, J., Asturiano, J.F., 2013. Evaluation 692 of methods to determine sperm density for the European eel, Anguilla anguilla. Reprod. Domest. 693 Anim. 48, 936-944.

694 Sørensen, S.R., Skov, P.V., Lauesen, P., Tomkiewicz, J., Bossier, P., Schryver, D.S., 2014. Microbial 695 interference and potential control in culture of European eel (Anguilla anguilla) embryos and 696 larvae. Aquaculture 426, 1-8.

697 Sørensen, S.R., Tomkiewicz, J., Munk, P., Butts, I.A.E., Nielsen, A., Lauesen, P., Graver, C., 2016. 698 Ontogeny and growth of early life stages of captive-bred European eel. Aquaculture 456, 50-61.

699 Stoeckel, J.N., 2000. A method for viewing the germinal vesicle in oocytes of commercial catfishes. $700 \quad$ North Amer. Journ. Aqua. 62, 240-247.

701 Tang, H., Liu, Y., Li, J., Li, G., Chen, Y., Yin, Y., Guo, Y., Cheng, C.H.K., Liu, X., Lin, H., 2017. LH 702 signaling induced ptgs $2 a$ expression is required for ovulation in zebrafish. Mol. Cell. Endocrinol. $703 \quad 447,125-133$.

704 Thomas, P., Pang, Y., Filardo, E.J., Dong, J., 2005. Identity of an estrogen membrane receptor coupled 705 to a $\mathrm{G}$ protein in human breast cancer cells, Endocrinology 146, 624-632.

706 Tomkiewicz, J., 2012. Reproduction of European Eel in Aquaculture (REEL): Consolidation and new 707 production methods. DTU Aqua Report No 249-2012. National Institute Aquatic Resources, 708 DTU, 47 p.

709 Tomkiewicz, J., Kofoed, T.M.N., Pedersen, J.S., 2011. Assessment of testes development during 710 induced spermatogenesis in European eel Anguilla anguilla. Mar. Coast. Fish. 3, 106-118. 
711 Tyler, C.R., Pottinger, T.G., Coward, K., Prat, F., Beresford, N., Maddix, S., 1997. Salmonid folliclestimulating hormone (GtH I) mediates vitellogenic development of oocytes in the rainbow trout, Oncorhynchus mykiss. Biol. Reprod. 57, 1238-1244.

714 Unuma, T., Hasegawa, N., Sawaguchi, S., Tanaka, T., Matsubara, T., Nomura, K., Tanaka, H., 2011. 715 Fusion of lipid droplets in Japanese eel oocytes: Stage classification and its use as a biomarker 716

Vidal, B., Pasqualini, C., Le Belle, N., Holland, M.C.H., Sbaihi, M., Vernier, P., Zohar, Y., Dufour, S., 2004. Dopamine inhibits luteinizing hormone synthesis and release in the juvenile European eel: a neuroendocrine lock for the onset of puberty. Biol. Reprod. 71, 1491-1500.

Wallace, R.A., 1985. Vitellogenesis and oocyte growth in nonmammalian vertebrates. In: Browder, L.W. (Ed.), Developmental Biology. Plenum Press; New York, pp. 127-177.

Wallace, R.A., Selman, K., 1981. Cellular and dynamic aspects of oocyte growth in teleosts. Am. Zool. 21, 325-343.

Watson, C.S., Gametchu, B., 1999. Membrane-initiated steroid actions and the proteins that mediate them. Proc. Soc. Exp. Biol. Med. 220, 9-19.

Yamamoto, K., Yamauchi, K., 1974. Sexual maturation of Japanese eel and production of eel larvae in the aquarium. Nature. 251, 220-222.

Yamauchi, K., 1990. Studies of gonadal steroids involved in final gonadal maturation in the Japanese eel, Anguilla japonica, a review. Inte. Revue. Ges. Hydrobiol. 75, 859-860.

Yoshiura, Y., Suetake, H., Aida, K., 1999. duality of gonadotropin in a primitive teleost, Japanese eel (Anguilla japonica). 114, 121-131.

Zeleznik, A.J., Midgley, J.R., Reichert, J.R., 1974. Granulosa cell maturation in the rat: increased binding of human chorionic gonadotropin following treatment with follicle-stimulating hormone in vivo. Endocrinol. 95, 818-825.

Zohar, Y., Muñoz-Cueto, J.A., Elizur, A., Kah, O., 2010. Neuroendocrinology of reproduction in teleost fish. Gen. Comp. Endocrinol. 165, 438-455. 


\section{Legends}

Figure 1: Oocytes at each sampling point.

740 Photomicrographs showing examples of oocytes at the most advanced stage of development from the

741 biopsy samples taken a) before SPE priming, b) before DHP injection and c) ovulated eggs cleared in

742 Serra's liquid. GV: germinal vesicle and LD: lipid droplet.

\section{$743 \quad$ Figure 2: Expression of gonadotropin receptors.}

744 Boxplots representing expression of gonadotropin receptors (fshr, lhcgr1 and lhcgr2) in ovarian

745 biopsies taken at the time of administration of the SPE primer (SPE) and DHP injection (DHP) as well 746 as ovulated eggs (EGG) in both high- $(n=5)$ and low-quality $(n=5)$ groups. The bold line inside each

747 box represents the median, lower and upper sides of each box represent the lower and upper quartile 748 (25\% and $75 \%)$ and whiskers extend to the most extreme data point, no more than 1.5 times the 749 interquartile distance. Data points outside the boxplot are classed as "outliers". Significant differences 750 between groups are identified with "**" when $p<0.05$; “**” when $p<0.01$ and “***” when $p<0.001$.

\section{$751 \quad$ Figure 3: Expression of estrogen receptors.}

752 Boxplots representing expression of nuclear (esr 1, esr2a) and membrane estrogen receptors (gpera and 753 gperb) in ovarian biopsies taken at the time of administration of the SPE primer (SPE) and DHP 754 injection (DHP) as well as in ovulated eggs (EGG) in both high- $(n=5)$ and low-quality (n=5) groups.

755 The bold line inside each box represents the median, lower and upper sides of each box represent the 756 lower and upper quartile (25\% and $75 \%)$ and whiskers extend to the most extreme data point, no more than 1.5 times the interquartile distance. Significant differences between groups are identified with "**" 758 when $\mathrm{p}<0.05$ and “**”, when $\mathrm{p}<0.01$ 


\section{Figure 4:}

760 Oocytes in three different maturational stages from an ovarian biopsy taken before the SPE priming

761 injection. 1: small and opaque oocytes; 2: large oocytes with darker cytoplasm; 3: large oocytes with 762 transparent cytoplasm and migratory nucleus.

763

\section{Figure 5: Lipid droplet diameter.}

765 Boxplot representing the lipid droplet diameter at the time of administration of the SPE priming (SPE) 766 and DHP injection (DHP), as well as in ovulated eggs (EGG) in both high- (n=5) and low-quality ( $\mathrm{n}=5)$

767 groups. The bold line inside each box represents the median, the lower and upper sides of each box 768 represent the lower and upper quartile (25\% and $75 \%)$ and whiskers extend to the most extreme data 769 point which is no more than 1.5 times the interquartile distance. Data points outside the boxplot are 770 classed as "outliers". Significant differences between egg groups are identified with an "*” when $p<$ 7710.05. 
Figure 1
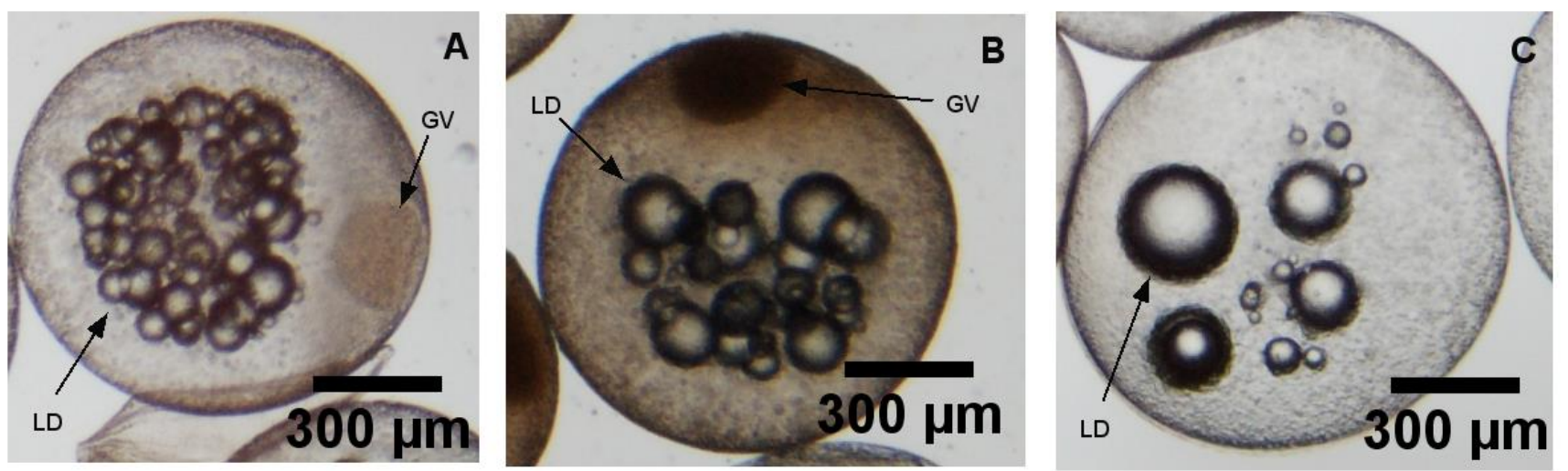
Figure 2
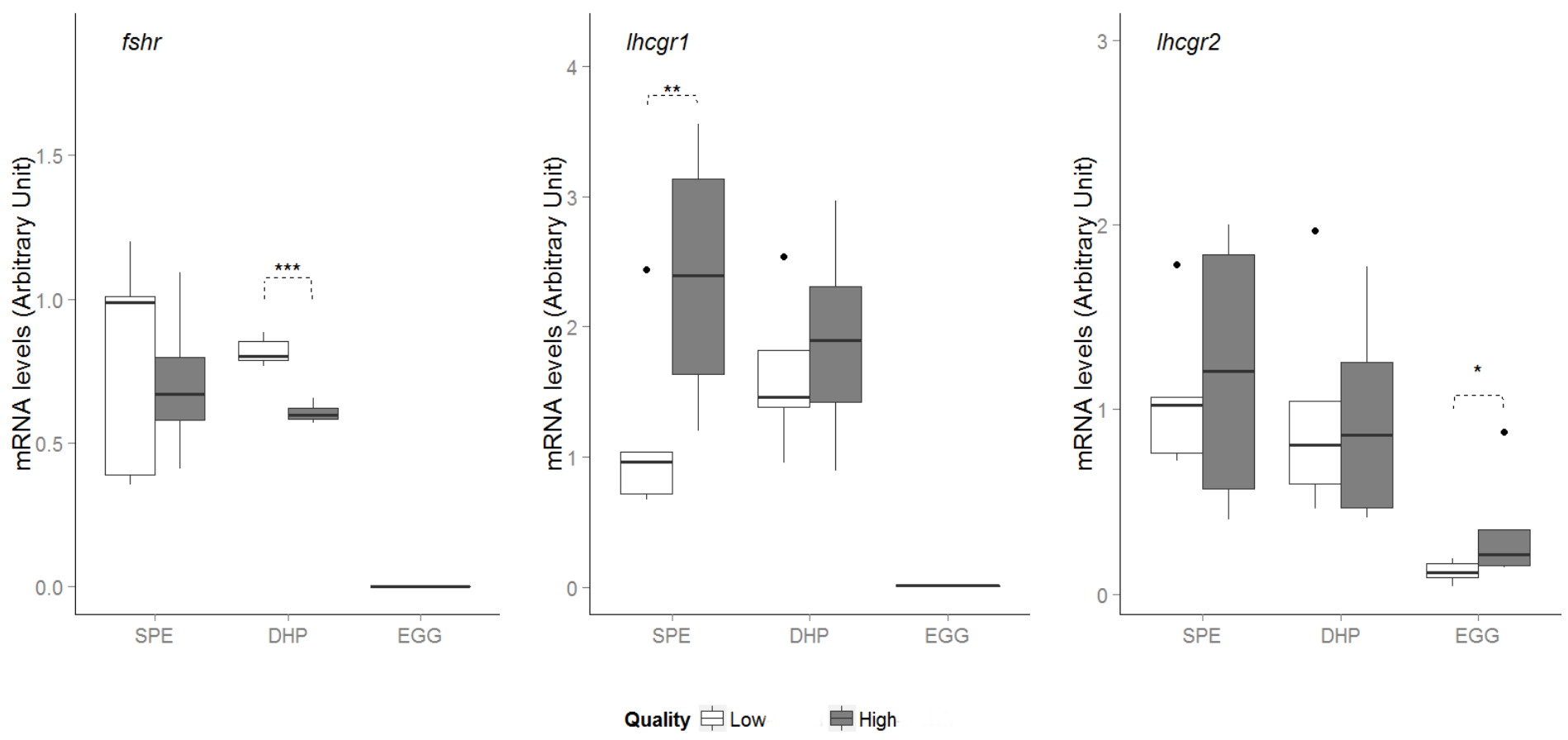
Figure 3
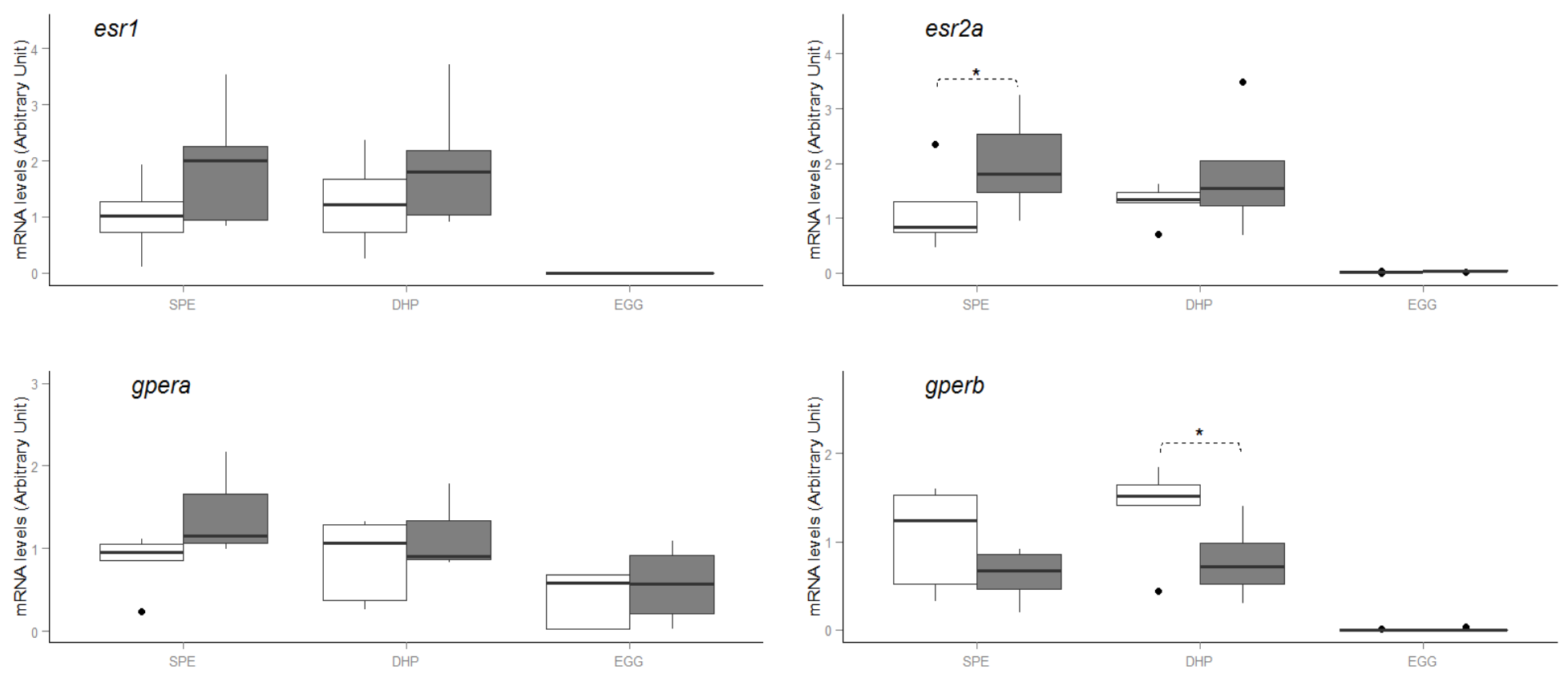

Quality 官 Low 审 High 
Figure 4

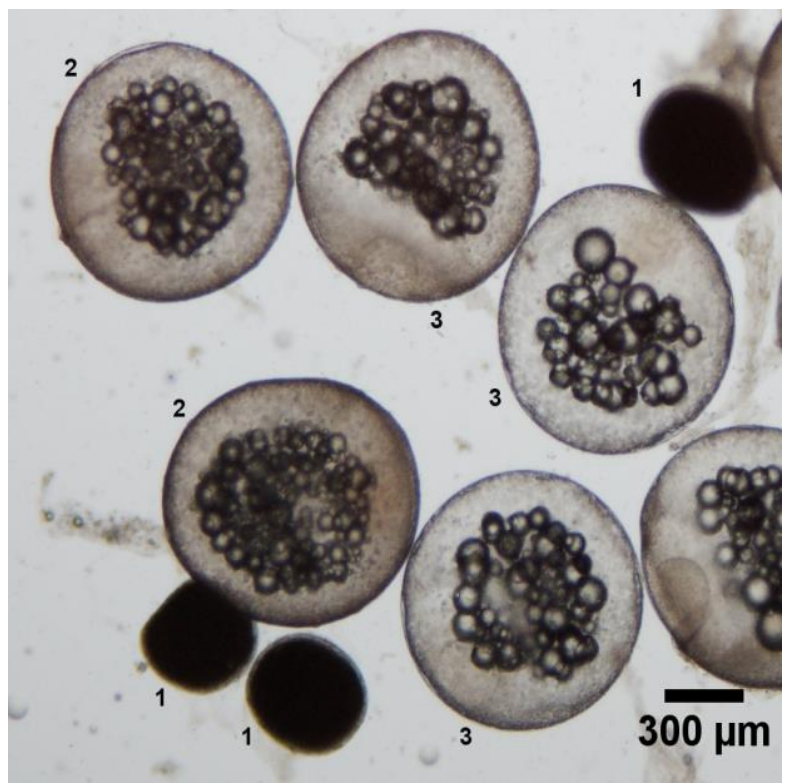


Figure 5

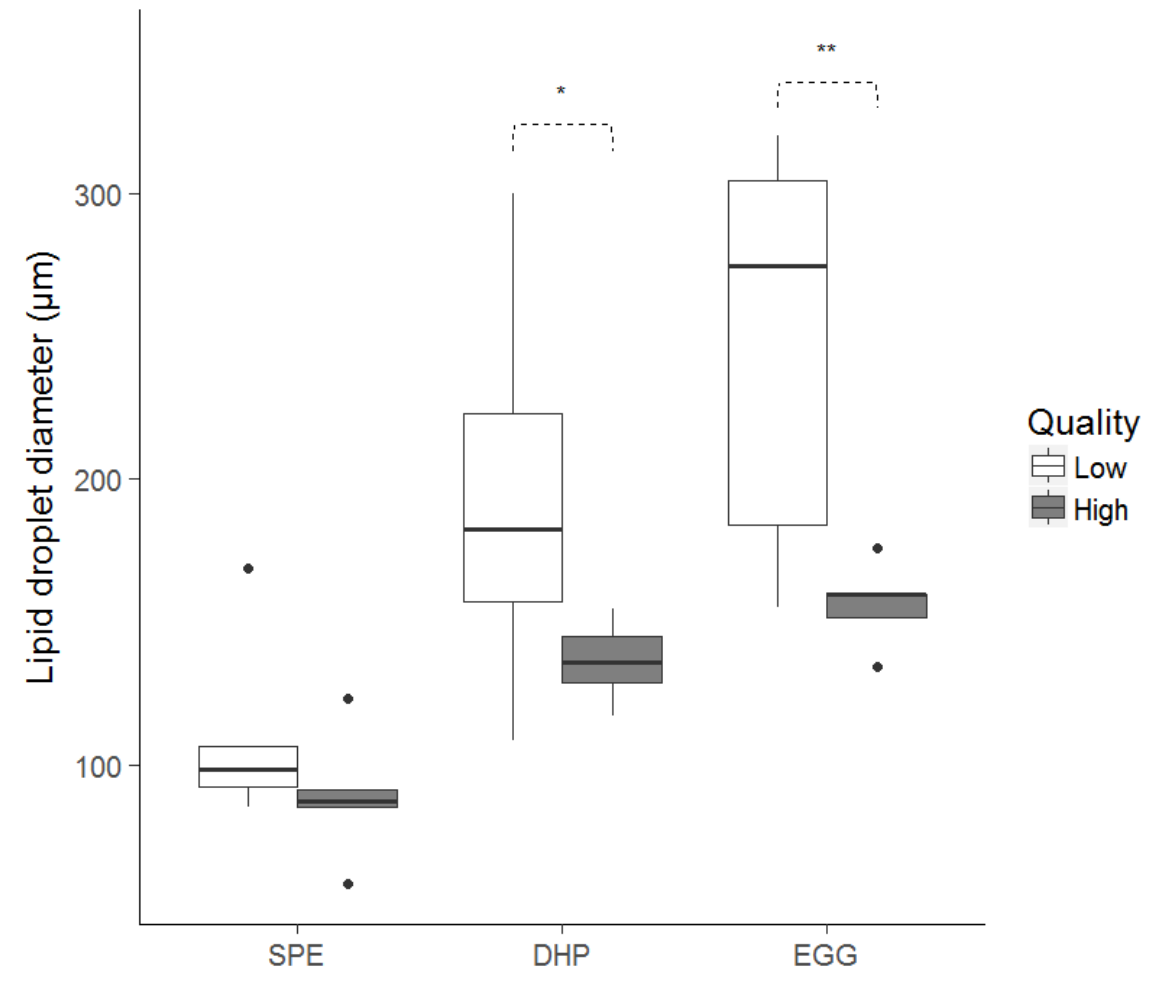


Table 1 Quantitative PCR primer sequences for gonadotropin receptors ( $f$ shr, lhcgrl and lhcgr2), nuclear estrogen receptors (esr1, esr $2 a$, esr $2 b$ ), membrane estrogen receptors (gpera and gperb) and reference gene (18s).

\begin{tabular}{|c|c|c|c|c|c|}
\hline Name & Sequence $\left(5^{\prime}-3^{\prime}\right)$ & Orientation & Accession number & Amplicon size (bp) & Reference \\
\hline \multirow[t]{2}{*}{$f_{s h r}$} & CCTGGTCGAGATAACAATCACC & Forward & LN831181 & 148 & Maugars and Dufour (2015) \\
\hline & AATCTTGGAGAAATCAGGCAGT & Reverse & & & \\
\hline \multirow[t]{2}{*}{ lhcgrl } & GCGGAAACACAGGGAGAAC & Forward & LN831182 & 155 & Maugars and Dufour (2015) \\
\hline & GGTTGAGGTACTGGAAATCGAAG & Reverse & & & \\
\hline \multirow[t]{2}{*}{ lhcgr2 } & GTTTCCTGACCTATCGGCTATT & Forward & LN831183 & 132 & Maugars and Dufour (2015) \\
\hline & GGTTGAGGTACTGGAAATCGAAG & Reverse & & & \\
\hline \multirow[t]{2}{*}{ esrl } & GCCATCATACTGCTCAACTCC & Forward & CUH82767 & 76 & Lafont et al., (2015) \\
\hline & CCGTAAAGCTGTCGTTCAGG & Reverse & & & \\
\hline \multirow[t]{2}{*}{ esr $2 a$} & TGTGTGCCTCAAAGCCATTA & Forward & CUH82768 & 169 & Lafont et al., (2015) \\
\hline & AGACTGCTGCTGAAAGGTCA & Reverse & & & \\
\hline \multirow[t]{2}{*}{$e s r 2 b$} & TGCTGGAATGCTGCTGGT & Forward & CUH82769 & 123 & Lafont et al., (2015) \\
\hline & CCACACAGTTGCCCTCATC & Reverse & & & \\
\hline \multirow[t]{2}{*}{ gpera } & CAACTTCAACCACCGGGAGA & Forward & CUH82770 & 170 & Lafont et al., (2015) \\
\hline & TGACCTGGAGGAAGAGGGACA & Reverse & & & \\
\hline \multirow[t]{2}{*}{ gperb } & AACCTGAACCACACGGAAA & Forward & CUH82771 & 170 & Lafont et al., (2015) \\
\hline & TGACCTGGAAGAAGAGGGACA & Reverse & & & \\
\hline \multirow[t]{2}{*}{$18 \mathrm{~s}$} & CTCAACACGGGAAACCTCAC & Forward & FM946070 & 118 & \\
\hline & AGACAAATCGCTCCACCAAC & Reverse & & & \\
\hline
\end{tabular}


Table 2 Information and group assignment about female eels and resulting egg batches used in the present study, including initial length, $\left(\mathrm{L}_{\mathrm{i}}\right)$ and body weight $\left(\mathrm{BW}_{\mathrm{i}}\right)$, volume of eggs stripped, floating fraction (\%), fertilization success (\%), hatching success $(\%)$ and larval survival (\%) at 3 days post hatch (dph).

\begin{tabular}{|c|c|c|c|c|c|c|c|c|}
\hline $\begin{array}{l}\text { Female } \\
\text { No. }\end{array}$ & $\mathrm{L}_{\mathrm{i}}(\mathrm{cm})$ & $\mathrm{BW}_{\mathrm{i}}(\mathrm{g})$ & Eggs (g) & Floating & Fertilization & Hatching & Survival $3 \mathrm{dph}$ & Group \\
\hline 1. & 70 & 693 & 322 & 99 & 68 & 65 & 67 & high-quality \\
\hline 2. & 67 & 574 & 324 & 99 & 99 & 80 & 93 & high-quality \\
\hline 3. & 60 & 433 & 229 & 99 & 69 & 55 & 83 & high-quality \\
\hline 4. & 78 & 1014 & 335 & 95 & 97 & 19 & 13 & high-quality \\
\hline 5. & 86 & 1444 & 571 & 50 & 80 & 67 & 78 & high-quality \\
\hline 6. & 79 & 1019 & 372 & 25 & 84 & 4 & 0 & low-quality \\
\hline 7. & 63 & 414 & 200 & 90 & 15 & 5 & 0 & low-quality \\
\hline 8. & 92 & 1334 & 586 & 99 & 20 & 0 & 0 & low-quality \\
\hline 9. & 62 & 426 & 195 & 50 & 25 & 0 & 0 & low-quality \\
\hline 10. & 60 & 459 & 133 & 100 & 96 & 4 & 0 & low-quality \\
\hline
\end{tabular}


Table 3 Pearson's correlation coefficient $\mathrm{R}$ and $p$-value for the linear regressions between gene expression at the time of SPE priming (SPE), DHP injection (DHP) and ovulated eggs (EGG), and hatching and fertilization success $(n=10)$.

\begin{tabular}{|c|c|c|c|c|c|}
\hline \multirow[t]{2}{*}{ Gene } & \multirow[t]{2}{*}{ Time point } & \multicolumn{2}{|c|}{ Hatching } & \multicolumn{2}{|c|}{ Fertilization } \\
\hline & & $\mathrm{R}$ & $p$ & $\mathrm{R}$ & $p$ \\
\hline \multicolumn{6}{|l|}{ fshr } \\
\hline & SPE & 0.23 & 0.529 & -0.20 & 0.577 \\
\hline & DHP & -0.79 & 0.012 & -0.46 & 0.213 \\
\hline & EGG & NA & NA & NA & NA \\
\hline \multicolumn{6}{|l|}{ lhcgrl } \\
\hline & SPE & 0.68 & 0.032 & 0.10 & 0.780 \\
\hline & DHP & 0.36 & 0.314 & -0.38 & 0.281 \\
\hline & EGG & -0.17 & 0.637 & -0.17 & 0.636 \\
\hline \multicolumn{6}{|c|}{ lhcgr 2} \\
\hline & SPE & 0.00 & 0.999 & 0.42 & 0.223 \\
\hline & DHP & -0.24 & 0.512 & 0.40 & 0.250 \\
\hline & EGG & 0.05 & 0.892 & 0.32 & 0.397 \\
\hline \multicolumn{6}{|l|}{ esrl } \\
\hline & SPE & 0.54 & 0.111 & -0.11 & 0.762 \\
\hline & DHP & 0.41 & 0.236 & -0.33 & 0.351 \\
\hline & EGG & NA & NA & NA & NA \\
\hline \multicolumn{6}{|l|}{ esr $2 \alpha$} \\
\hline & SPE & 0.60 & 0.067 & 0.05 & 0.894 \\
\hline & DHP & 0.49 & 0.154 & -0.11 & 0.762 \\
\hline & EGG & 0.60 & 0.064 & 0.35 & 0.316 \\
\hline \multicolumn{6}{|l|}{ gpera } \\
\hline & SPE & 0.34 & 0.331 & 0.56 & 0.094 \\
\hline & DHP & 0.29 & 0.419 & 0.46 & 0.183 \\
\hline & EGG & 0.06 & 0.865 & 0.38 & 0.275 \\
\hline \multicolumn{6}{|l|}{ gperb } \\
\hline & SPE & -0.44 & 0.204 & -0.62 & 0.058 \\
\hline & DHP & -0.31 & 0.413 & -0.21 & 0.584 \\
\hline & EGG & $\mathrm{NA}$ & $\mathrm{NA}$ & $\mathrm{NA}$ & $\mathrm{NA}$ \\
\hline
\end{tabular}

